\title{
V odrazu našich vzpomínek. Rodinná amatérská fotografie jako nástroj paměti ${ }^{1}$
}

\author{
In the Image of our Remembrance: Amateur Family Photography \\ as an Instrument of Memory \\ Jindra Tichá
}

\begin{abstract}
The medium of photography and its relation to reality has been intensively discussed since the start of digitalization. Amateur family photography as a social entity is mostly determined by its role in family life. As an instrument of collective memory of family, it usually functions to reinforce this social group. To discover its manipulation of reality, we must also consider its importance as a technique of reproduction. Based on the documentation of actual rituals, the practice of photography plays a role in constituting family history as seen by the family members themselves.
\end{abstract}

KEY WORDS amateur photograhy, collective memory, family

Fotografie ustavuje memento mori světa, dovoluje mu, aby se stal fotografem sebe sama.

(Batchen, Burning with Desire, s. 212)

\section{Obraz paměti}

Pamět' individuální a kolektivní tvoří zásadní součást naší identity. Svým př́íchodem způsobilo fotografické médium revoluci v jejím uchovávání, když umožnilo takovou míru přesnosti, jaké vizuální pamět' nikdy předtím nemohla dosáhnout. Snad nejširší oblast využívající dokumentačního potenciálu fotografie tvoří rodinné amatérské snímky. V teorii fotografie jinak často diskutované a zpochybňované spojení fotografického zobrazení se skutečností se $\mathrm{v}$ praxi setkává $\mathrm{s}$ touhou zaznamenávat naše blízké, uchovávat jejich podobu navzdory toku času, a činí tak z fotografování jednu z nejrozšířenějších sociálních aktivit. S doposud nebývalým využitím fotografického média, které je dáno také jeho technologickými změnami v souvislosti s nástupem digitalizace, nabývají současně na síle spory ohledně míry pravdivosti tohoto záznamu. Na př́ikladu rodinné amatérské fotografie bych ráda popsala, jakým způsobem fotografické médium do uchovávání paměti vstupuje, jak pamět’ proměňuje a jaký je jeho vliv na podobu rodinné historie.

Sociální studia. Fakulta sociálních studií Masarykovy univerzity, 1/2010. S. 89-100. ISSN 1214-813X.

1 Text vznikl na základě finanční podpory Grantové agentury Univerzity Karlovy. 
Bude mne zajímat rodinná amatérská fotografie především jako sociálně podmíněná entita, jejíž obrazová složka je konstituována právě na základě její funkce uvnitř rodiny. V touze po odkrytí vztahu mezi fotografíi a pamětí tedy nebudou předmětem mého zájmu obrazové principy rodinné fotografie ani její estetická stránka. Jestliže její podoba je převážně dána její sociální rolí, je na místě obrátit pozornost ještě před „ustálení“ fotografického obrazu, k tomu, co jeho vzniku předcházelo. Soustředím se tedy na samotnou praktiku fotografování a její roli v rámci rodinného života. ${ }^{2}$

Přitom budu sledovat koncepci rodinné kolektivní paměti tak, jak ji definoval filozof a sociolog Maurice Halbwachs (1992) a ze které vychází také Pierre Bourdieu (1990). Ráda bych reagovala zejména na Bourdieho průkopnické poznatky ohledně rodinné amatérské fotografie z hlediska jejího sociálního fungování. Ani Bourdieu se z mého pohledu totiž nevyhnul úskalí, které provází prolnutí sociologie a teorie fotografie či vizuálních studií, tedy př́ilišnému uvěznění pouze $\mathrm{v}$ jednom $\mathrm{z}$ diskurzů. Za účelem jejich vyvážení budu sledovat rodinné amatérské snímky jak z perspektivy teorie fotografie, tak sociologie. Ústřední linie argumentů $\mathrm{k}$ tématu pritom bude vést od Halbwachsovy koncepce paměti přes Bourdieuho práci až k poznatkům Ervinga Goffmana (1986). Vedle Goffmanovy analýzy rámců mě bude zajímat jeho teze o „dokumentačním klíčováni“, týkající se vzestupné tendence využívání reprodukčních technik ve společnosti.

\section{Skutečná fotografie}

Pojetí fotografického média jako nástroje paměti se datuje již od dob jeho počátku. Schopnost „zmrazit“ určitý okamžik, se brzy po vynálezu fotografie stala hlavním předpokladem při koncipování její identity jako svébytného média. (Tento potenciál fotografie sehrál neméně důležitou roli v době vizitkové éry, kdy fotografie získávala na oblíbenosti v masové míře.) „Fotografie umožnila návrat již pominuvšího - čímž přinesla i proroctví budoucích návratů. At’ už bylo její nominální téma jakékoli, fotografie ustavovala vizuální zápis míjení času, čímž také poukazovala k nevyhnutelnému zániku každého diváka“ (Batchen 2004: 344).

Ostatně i podle Rolanda Barthese tkví noema fotografie právě v jejím odkazu k minulosti, ve vědomí „toto bylo“ (Barthes 2005). Zároveň s sebou fotografické médium stále nese, zejména $\mathrm{v}$ prípadě analogové fotografie, stigma $\mathrm{v}$ podobě požadavku po důvěryhodnosti tohoto vizuálního sdělení. Vědomí „toto vidíme“ s sebou přináší také poněkud zavádějící předpoklad, že „toto bylo“ tak, jak to vidíme. Přitom ale právě Barthesův známý citát vyjadřuje rezignaci na pravdivý přepis skutečnosti, kterého by bylo možné dosáhnout prostřednictvím fotografie (Barthes 2005). Stěžejním charakteristickým rysem a zároveň jedinečným prínosem fotografie zůstává pro Barthese její svázanost s referentem a podmínka přítomnosti referentu před objektivem fotoaparátu v okamžiku zmáčknutí spouště. Barthesovo přirovnání

2 Žádnou výjimkou není ani pohled na amatérskou rodinnou fotografii z hlediska jejího obrazu a estetického působení (např́ikad Frizot 2006). Mým záměrem ale není pohled na tuto oblast fotografie jako již daného obrazu, potažmo artefaktu, ale pátrání po př́činách jejího vzniku, po tom, proč a za jakých okolností fotografické snímky vznikají a jak fungují v rámci kontextu rodiny a společnosti. 
fotografie ke stopě či posmrtné masce vychází z přesvědčení o jejím indexickém vztahu ke skutečnosti. ${ }^{3}$ Ve své analogové podobě představuje fotografie pro tohoto autora důkaz př́tomnosti referenta, bez ohledu na pravdivost jeho zobrazení. Označuje fotografii př́imo jako „bizarní médium“, jako „novou formu halucinace“, která je nepravdivá na rovině percepce, ale pravdivá na rovině času (Barthes 2005: 107). Vědom si klamné představy o fotografii jako objektivním záznamu skutečnosti, vydává se Barthes při interpretaci fotografie své zemřelé matky cestou subjektivní reflexe. Na prvních stránkách Světlé komory se proklamativně zř́ká jakéhokoli reduktivního systému a uzavírá se při pohledu na fotografie pouze do sebe. „Učinil jsem tedy sebe sama mírou fotografického ,vědění‘,“ píše (Barthes 2005: 16). Jeho metoda nám tedy sice může přinést určité uspokojení v touze po narativním způsobu výkladu jednotlivých fotografií, neřekne nám ale mnoho o jejich funkci uvnitř rodiny ani o roli, jakou zaujímají v souvislosti s uchováváním rodinné paměti. Blíže ke kolektivní paměti posouvá Barthesovy úvahy Annette Kuhn (2002), když nahrazuje jeho „toto bylo“ svým „takoví jsme byli“" Rodinné fotografie totiž podle Kuhn mají sloužit ani ne tak jako doklad, že jsme byli, ale ukazovat, jací jsme v momentu zachycení byli. Tedy evokovat vzpomínky, které mají často velmi málo co do činění s tím, co se opravdu na fotografí́ch nachází (Kuhn 2002: 13). Současně tím Kuhn trefně upozorňuje na idealizující podobu rodinné historie prezentované $\mathrm{v}$ albech amatérských fotografií.

Manipulace s vlastní rodinnou pamětí je umožněna právě rozporem mezi tím, co se odehrálo před objektivem fotoaparátu, a zachyceným obrazem. Míra vizuální př́ibuznosti fotografického obrazu se zobrazovanou skutečností vychází z mechanické povahy fotografického záznamu a stojí za využitím fotografie jako nástroje paměti. $O$ to palčivěji vyvstala otázka fotografického obrazu jako nositele svědectví s prí́chodem digitálních technologií. Proces digitalizace totiž nejenže umožnil technicky manipulovat se zobrazovaným v neomezené míree, ale otevřel také možnost vytvořit zbrusu novou, virtuální realitu bez „hmatatelné“ předchozí vazby na skutečnost (míním tím, že virtuální realita nevyžaduje žádnou skutečnost, která by jí předcházela, narozdíl od reality zobrazované analogově). Pro W. J. Mitchella představuje nemanipulovaná analogová fotografie esenciální podobu fotografického média, kterou označuje jako „normální“ (Mitchell 1994). Protože manipulace fotografického obrazu vzniklého analogovou cestou je po technické stránce obtížná, tudíž zřídkakdy v běžné produkci praktikovaná, jako diváci očekáváme od fotografického obrazu v převážné většině př́ípadů pravdivou vizuální výpověd’ o skutečnosti. Podle Mitchella digitální fotografie svojí snadnou manipulovatelností mění samotný status fotografie, činíc všechny fotografické obrazy potenciálně měnitelné. Jak ale namítá Lev Manovich (2003), představovala př́ímá fotografie, o které uvažuje Mitchell, vždy pouze jednu tradici fotografického média, která $\mathrm{v}$ jeho rámci koexistovala $\mathrm{s}$ tradicemi (a podobami) dalšími (např. komerční fotografie), které počítaly i ve své analogové podobě s manipulací skutečnosti. Podle Manoviche tudíž nemohla digitální fotografie nikdy subvertovat „,normální“ fotografii, protože žádná taková nikdy neexistovala. Vedle zjevné problematičnosti Mitchellovy koncepce stavící na esenciální podobě fotografického média jako př́mého, nemanipulovaného záznamu rovněž doznává

3 V poslední době se však objevují hlasy zpochybňující samotnou indexickou povahu analogové fotografie (Batchen 1999). 
jistých trhlin představa o médiu prostém jakékoli manipulace. Také Geoffrey Batchen (1999) poukazuje na fakt, že dilema ohledně manipulace fotografického obrazu je spíše než otázkou etiky povahy rétorické, nebot' např́íklad snímky objevující se už v tradičních médiích (tedy novinách či časopisech) nebyly nikdy prosty manipulace. Nástup digitalizace tak, podle něj, vyvolal pouze potřebu tento fakt prriznat sobě i veřejnosti (Batchen 1999: 212). Batchen se však neomezuje pouze na oblast žurnalistické fotografie, ale jde ve své úvaze ještě dál, když označuje celé dějiny fotografie jako dějiny manipulací. „Vždyt’ co jiného je fotografie, než schopnost manipulovat světlo, expozici, chemické koncentráty, barevnost a tak dále," ptá se Batchen (1999: 349).

Představy o „nevinnosti“ analogového záznamu na rozdíl od digitálního se ukázaly jako klamné. Popsané spory vedené o míře manipulace fotografického média se skutečností se však odehrávaly převážně na poli tázání se po podstatě fotografie, v reakci na její údajnou relativizaci nástupem digitálních technologií. Proto se také týkaly především technické roviny práce $\mathrm{s}$ fotografickým médiem. Je samozřejmě možné diskutovat podíl fotografické technologie na „pravdivosti“ zobrazení, ale těžko se neshodnout na tom, že fotografie je vždy určitou interpretací skutečnosti, ostatně stejně jako naše vnímání okolního světa.

Vztahem individuální paměti ke skutečnosti a vnímání se zabýval už Henri Bergson v knize Hmota a pamět' (Bergson 2003). Bergson situuje hmotu na půl cesty mezi reprezentaci ducha a objektivní věc. Předmět sice existuje vně nás, ale v podstatě má povahu obrazu (Fulka 2003). Jednotlivé obrazy, které z okolí prrijímáme, však málo znamenají, pokud se je nepodaří spojit $\mathrm{v}$ nám srozumitelnou výpověd’. A $\mathrm{k}$ tomu nám dopomáhá právě pamět'. Podle Bergsona neexistuje vnímání, jež by nebylo prostoupeno vzpomínkami. Naše př́tomné zážitky se tak mísí s tisíci detaily z naší minulé zkušenosti a tyto vzpomínky většinou mění podobu našich reálných vjemů, z nichž pak zaznamenáváme jenom to, co potřebujeme. A je to právě pamět', která vnáší do plurality okamžiků návaznost jednoho na druhý.

Henri Bergson ve svých úvahách připodobňuje princip našeho vnímání $\mathrm{k}$ fungování kinematografického či fotografického aparátu. Jenže místo abychom poznávali skutečný pohyb věcí, bereme z nich pouze „mžikové snímky“, které znovu uměle skládáme. Jelikož prezence podle něj nemůže být ve vědomí jinak než jako reprezentace (Fulka 2003), považuje naše vnímání za nedokonalé až povrchní. Každý mechanismus, který nám má napomoci vysvětlit jednání, ho nevyhnutelně také kontroluje. Podobně rodinné amatérské fotografie jsou výsledkem selektivní činnosti, která většinou vede k idealizované interpretaci rodinné historie. Jakým způsobem tedy fotografické médium jako prostředek zaznamenávání do tohoto výběru vstupuje a jak se projevuje jeho vliv na podobě rodinné paměti?

\section{Fotografie a rodina}

Jednou z př́ícin vysoké oblíbenosti fotografování na amatérské úrovni, na rozdíl např́iklad od hry na hudební nástroj, je podle Pierra Bourdieu (1990: 13) nenáročnost osvojení si základních postupů, tj. zvládnutí aparátu. Také díky legitimizovanému sepjetí fotografie se skutečností se poměrně záhy stal fotoaparát téměř nepostradatelnou součástí vybavení domácností a rozšířeným způsobem dokumentování rodinných událostí. Způsob práce vět- 
šny amatérských fotografi̊ nesouvisí ani tak s jejich technickou vybaveností, ale vyplývá $\mathrm{z}$ role, jakou praktika fotografování $\mathrm{v}$ rámci rodinného života zaujímá.

Richard Chalfen (1987: 50) upozornil na to, jak samozřejmě je domácí tvorbě přidělována nálepka „naivní“ při zohledňování jejích technických nedostatků projevujících se například v malém zájmu o kompozici. Ta zde slouží především ke zřetelnému zpodobnění objektů zájmu, takže jasnost zobrazení se stává ovládajícím záměrem fotografování v rámci rodiny. Proto je zpravidla zapotřebí, aby se všichni aktéři vešli do záběru, aby byli natočení směrem $\mathrm{k}$ fotoaparátu tak, aby byly viditelné jejich tváře, tedy aby bylo lehce rozpoznatelné, kdo všechno do skupiny patří. Osoby vy̌šsí proto také při skupinovém fotografování stojí za osobami nižšími. Účelem snímku není estetizace fotografovaného tématu, ale jeho co možná pro budoucnost nejzřetelnější zaznamenání. Jakkoli se estetika domácí tvorby může jevit jako transparentní či naivní, vyhrazení vědomého záměru pouze pro umělce vypovídá o elitářském snobství (Moran 2004).

Fotografování jako takové bývá zpravidla spojováno s částí rodinného života, jež se odehrává v rámci tzv. volného času (leisure). Podle Dona Slatera (1999) je tímto režimem volného času silně ovlivněna. Thorstein Veblen (1999: 34-57) označuje neproduktivní trávení času jako „zahálku“. Tomu podle něj odpovídá rejstřík námětů zvolených $\mathrm{k}$ fotografování i forma zobrazení nabývající nejčastěji podobu fotografické momentky. Nejenže se Veblenem popisovaná „okázalá zahálka“ stává pro rodinu ukazatelem prestiže a úspěchu ve společnosti, v reprodukované podobě slouží také jako zdroj pozitivních vzpomínek na společně strávené chvíle. Výsledkem je však dosti idealizovaný obraz rodiny, jejiž historie se při zpětném pohledu sestává povětšinou z rodinných oslav, výletů na hory či dovolených strávených u moře. Jen výjimečně bychom například mezi rodinnými amatérskými fotografiemi nalezli snímky pracujících členů rodiny.

Jo Spence (2003) hovoří v této souvislosti o potřebě foto-terapie založené na reflexi našeho vlastního alba rodinných fotografií. Jelikož tyto fotografie stěží kdy zobrazují souboje, trápení a skryté touhy jednolivých členů rodiny, tito mohou být pak frustrováni rolí, do které jsou vtaženi. Fotoalba tak většnou vypovídají více než o samotné rodinné historii o konvencích jejího zobrazování. Proto Spence nabádá v rámci své terapie nejprve hovořit o našich stávajících rodinných fotografiích, abychom odkryli vzpomínky, které vyvolávají, a poté se soustředili na vytvoření nového rodinného alba, v němž budou zaznamenány i okamžiky, které jsou zpravidla vynechávány, jako jsou např́iklad nemoci, úmrtí, ale třeba také rozvod. ${ }^{4}$ Spence, stejně jako již zmiňovaná Anette Kuhn, pokračuje v cestě za rodinnou fotografií, kterou vytyčil už Roland Barthes. Volí tedy metodu vizuální autobiografie, aby

4 Ze sociologického hlediska je přinejmenším zajímavé připomenout zcela opačný př́stup k rodinné fotografii, který můžeme sledovat v případě fotografie umělecké. Tyto snímky založené na principu fotografování vlastní rodiny zobrazují převážně právě okamžiky nelichotivé, v touze po podání pravdivého obrazu rodiny. Mám na mysli např́ílad slavný soubor fotografií Richarda Billinghama, jenž dokumentárním způsobem zachycuje svého otce Raye, alkoholika, a matku Liz se zálibou v tretkách a skládání puzzle. Rodinná fotografie se zde vymaňuje z obvyklých sociálních rámců, jelikož motivy pro zaznamenávání rodinného života nevycházejí primárně z potřeb udržení sociální skupiny (Billingham 2000). 
se dostala pod povrch zobrazeného, $\mathrm{k}$ př́běhům ukrytým za idealizovanou rodinnou historií prezentovanou fotografiemi. Pro nás je ale směrodatná především otázka, z jakého důvodu jsou pro rodinu zaznamenáníhodné právě tyto a ne jiné okamžiky? Jakkoli můžeme připustit determinaci rodinné amatérské fotografie jejím zařazením jako volnočasové aktivity, motivace $\mathrm{k}$ sebeprezentaci rodiny právě tímto způsobem je třeba hledat ještě hlouběji.

\section{Kolektivní pamět rodiny}

Jak popsal francouzský sociolog Pierre Bourdieu (1990), je rodinná amatérská fotografie determinována především svojí funkcí sociální. Tato její funkce přitom vychází do značné míry právě z uchopení média fotografie jako nástroje paměti. $\mathrm{V}$ př́ípadě rodiny přitom jde jak o pamět' individuální, tak kolektivní: ta je pro pochopení motivů vedoucích $\mathrm{k}$ fotografování a jeho role unvitř skupiny stěžejní. Bourdieu přitom navazuje především na koncepci kolektivní paměti, jak ji definoval v období od 20. do 40. let 20. století francouzský sociolog a filozof Maurice Halbwachs (1992).

Ačkoli byl Halbwachs zpočátku pod vlivem Bergsonovy filozofie, pro jeho koncepci kolektivní paměti byl zásadní pozdější obrat směrem k sociologii Emila Durkheima. Sám údajně požádal Durkheima o pomoc při své intelektuální cestě od Bergsonova individualismu k vědeckému objektivismu (Halbwachs 1992: 8). Návaznost pojetí kolektivní paměti Maurice Halbwachse na myšlenky jeho průvodce sociologickým světem je zvláště patrná ve srovnání s Durkheimovou koncepcí kolektivních reprezentací. Jak píše Durkheim (2002) v knize Elementárni formy náboženského života, slouží náboženské rituály vnějškově k upevňování vztahu mezi světským a posvátným, ve skutečnosti jde ale o obnovování pocitu vzájemnosti mezi členy společnosti. Kolektivní rituály, jako jsou svátky a jiné oslavy, jako protiklady ke všednímu času mají především sloužit k posílení soudržnosti společnosti. Zdrojem transcendentní zkušenosti pro její členy tedy, ačkoli si to neuvědomují, nejsou bohové, ale sama společnost, která trvá nezávisle na jejich životech a bude pokračovat i po jejich smrti. Podobně sledoval potřebu vědomí kontinuity skupiny $\mathrm{v}$ prŕpadě rodinné paměti $\mathrm{i}$ Maurice Halbwachs. Album rodinných amatérských fotografií můžeme vnímat jako zhmotnění této touhy po zachování rodinné historie, založené na přesvědčení, že rodina přesahuje svoje jednotlivé členy a bude trvat i po jejich smrti.

Halbwachs definuje kolektivní pamět' jako nikoli daný, ale sociálně konstruovaný pojem. Přestože je však kolektivní pamět’ vytvářena a živena koherentním společenstvím lidí, jsou to stále jeho jednotliví členové, kteří si pamatují. Mohli bychom proto nalézt současně tolik kolektivních pamětí, kolik těchto skupin či institucí ve společnosti existuje. ${ }^{5}$ Ve své knize On Collective Memory se zabývá v jedné z nejobsáhlejších kapitol právě kolektivní pamětí rodiny. Při jejím koncipování přitom vychází z přesvědčení, že minulost je převážně sociální konstrukcí. Rodinné vzpomínky podle něj nepředstavují pouze sled individuálních obrazů minulého, ale slouží současně jako modely, př́iklady chování, jako základní součásti

5 Podle Halbwachse přitom zůstává pouze jediná oblast lidské zkušenosti, která by nebyla zakořeněná v sociálním kontextu a struktuře, a sice sféra snů. Postrádá totiž na rozdíl od vzpomínek jakékoli uspořádání (Halbwachs 1992), 
učení se. Nejenže reprodukují minulost, ale vyjadřují také obecné postoje skupiny, její kvality i slabosti. Podle Halbwachse každá vzpomínaná rodinná události či osoba sestává ze dvou rovin: na jedné straně je to individuální obraz, který vytváríme na základě naší osobní zkušenosti, a na druhé straně jde o pohled z perspektivy skupiny, objasňující, proč je pro nás ona událost či osoba důležitá. Rodinné tradice jsou přitom vždy ovlivněny společností, ale přesto zůstávají pro každou rodinu odlišné, protože jsou utvářeny na základě jejího rodinného života a protože jejich role je především potvrzením rodinné soudržnosti a zabezpečením její kontinuity. $\mathrm{V}$ tomto směru upevňují rodinné fotografie náš smysl pro dějiny tím, že „poskytují narativní formát pro předávání rodinných legend a osobních př́běhư“ (Moran 2004: 84).

Není prritom podstatné, jakým způsobem jsme se stali součástí rodiny (zda narozením, sňatkem či jiným způsobem). Jako článek okruhu dané rodiny podléháme pravidlům a zvykům nezávislým na pocitech nás samotných, ale existujících v rodině ještě dávno před naším př́íchodem. Obdobnou důležitost přisuzují okamžiku začlenění se do rodiny jak Bourdieu, tak Halbwachs. At’ už došlo ke vstupu dalšího člena jakkoli, rodina tuto událost zpravidla datuje a zaznamenává její širší souvislosti (Halbwachs 1992). A co víc, podle Halbwachse si tuto událost připomeneme pokaždé, když je na nového člena upřena naše pozornost. To je také jeden z důvodů, proč tak významné postavení v rodinných albech zaujímají snímky dětí. Vedle potřeby dokumentovat jeho vývoj představuje narození dítěte pro rodinu ze sociologického hlediska důležitou součást uvědomování si svojí př́ślušnosti ke skupině a upevňování těchto vazeb (Bourdieu 1990). Jak vyplývá z Bourdieuho poznatků, existuje přitom úzká spojitost mezi př́tomností dítěte $\mathrm{v}$ rodině a vlastnictvím fotoaparátu. Podle výzkumu, který vedl v roce 1963 se 692 subjekty žijícími v Paříži, Lille a malých venkovských městech, více než dvě třetiny jeho respondentů tvořili př́ležitostní fotografové, kteří dokumentovali zejména rodinné oslavy či jiná společenská setkání nebo průběh dovolené. Přitom až $64 \%$ domácností $\mathrm{s}$ dětmi vlastní alespoň jeden fotoaparát, oproti $32 \%$ fotoaparátů v bezdětných domácnostech (Bourdieu 1990).

Bourdieu při svém uvažování o rodinné amatérské fotografii zohledňuje její roli jako prostředku zaznamenání; jako sociálně podmíněné entity. Vychází přitom z přesvědčení, že tito amatérští fotografové nemají estetické ambice, že motivace $\mathrm{k}$ fotografování vychází primárně z potřeby dokumentování života rodiny. Nezřídka vedeni přáním okolí po vyfotografování určitých okamžiků, hromadí v rodinném albu snímky, jejichž produkci vnímají podobně nevyhnutelně jako rodinné rituály, které zobrazují.

Určující je pro Bourdieuho pojetí rodinné paměti jako kolektivní, tedy sociálně konstruované. Podobně jako Maurice Halbwachs proto přisuzuje zásadní roli v rámci rodinného života významným událostem, jako jsou svatby, prázdniny, narození dítěte, oslavy narozenin, Vánoce a podobně. Tyto nazývá tzv. upevňovacími mechanismy, skrze které si její př́slušníci uvědomují svoji př́ślušnost ke skupině a stvrzují vazby se vzdálenějšími příbuznými. Zaznamenání těchto událostí pomocí fotografie pak má sloužit k posílení sociální soudržnosti (Bourdieu 1990). Čestné místo proto např́klad mezi rodinnými fotografiemi zaujímají skupinové snímky, na kterých je viditelné, kdo všechno ke skupině patří. Podle Halbwachse kolektivní pamět' vyplňuje prázdný prostor mezi střídajícími se obdobími vzrušujících událostí 
a obyklých zkušeností. Díky zachovávání rozmanitých slavnostních a obřadních činností a jejich připomínání zůstává pamět živá i během jinak prázdné, každodenní rutiny.

Obeznámení s kolektivní pamětí konkrétní rodiny přitom zůstává pro pochopení rodinné fotografie divákem zásadním aspektem. Na příkladu rituálu promítání či jiné podoby prezentace těchto snímků potvrzuje Bourdieu její důležitost. Prezentace se totiž stává pro nezainteresované diváky často dosti nudným zážitkem, neznalost kontextu činí z rodinných fotografí konvenční, stále se opakující obrázky, jejichž význam jim uniká.

\section{Individuální vzpomínky}

Jakkoli se může na základě technologického vývoje měnit obrazová složka rodinných fotografií, praktika fotografování sama o sobě se tím nijak nevyvazuje ze své tradiční funkce. Objektiv fotoaparátu je $\mathrm{v}$ kruhu rodinném stále namíren na tytéž pro skupinu zásadní momenty, sleduje stále obdobné objekty a intence (Bourdieu 1990). Přitom stejně jako patří vztahy mezi př́slušníky rodiny mezi ty, jež nikdy nemůžeme úplně zpřetrhat (jelikož bratři se nemohou rozhodnout, že již nebudou bratry), je rodinná fotografie nemyslitelná bez specifického vztahu mezi jejím autorem a fotografovaným objektem. V žádné jiné skupině, jak píše Halbwachs, není pozice individua tak předurčena, bez ohledu na to, jaké jsou jeho individuální touhy a potřeby. $Z$ takového předpokladu vychází také Bourdieu, když hovoří o tom, že rodinné fotografování je svázané se svojí sociální funkcí jako žádné jiné. Nemožnost oprostit jej od jeho dokumentačního účelu brání v rozvoji jiných intencí, potažmo autonomní estetiky. Podle něj by se spíše než k upomínce daly rodinné fotografie přirovnat k pomníku, tedy neměnnému monumentu minulých časů, vytvořenému s úctou $\mathrm{k}$ těm, kteří tu již nejsou.

Z pojetí Pierra Bourdieuho, který většinu své pozornosti upírá na pamět' kolektivní, se ovšem vytrácí role té individuální. Sepjetí se sociální funkcí je podle něj pro tuto fotografii natolik determinující, že eliminuje veškerou jedinečnost náležející individuálním vzpomínkách jednotlivých členů rodiny. Jak ale vyplývá z Halbwachsovy koncepce, i v př́padě rodinné kolektivní paměti jsou to stále vzpomínky jednotlivých členů, kteří si pamatují a na kterých je postavena. Rodinné amatérské fotografie mohou být výsledkem určitých konvenčních postupů, které odpovídají jejich sociální funkci, ale stále jsou zdrojem vzpomínání jednotlivých divákủ úzce svázaného s individuálním prožitkem. Vzpomínky na minulé události podle Halbwachse nelze docela oddělit od zážitků, které jim předcházely či které po nich následovaly. Naše současné vnímání ovlivňuje naše vědomí v okamžiku vzpomínání natolik, že jím nemohou nebýt naše vzpomínky ovlivněny. Proto žádná rodinná historie nemůže být neměnná, stejně jako se může měnit význam rodinné amatérské fotografie $v$ průběhu času (Moran 2004: 73). V určité fázi může takové album fotografií sloužit k sebepotvrzení rodiny jako soudržné jednotky a současně být později prostředkem, jak se s daným vizuálním zápisem rodinné historie vyrovnat.

Věř́m, že bychom po podrobném zkoumání mohli nalézt i na rodinných fotografiích individuální reflexi zobrazených událostí, ovšem pravděpodobně pouze za přispění jejich autorů. A samozřejmě by šlo o reflexi notně svázanou technikou, která, ačkoli se zdá, že činí fotoaparát snáze ovladatelný, v podstatě umožňuje stále menší možnost zásahu do procesu vzniku fotografie. Ovšem analyzovat individuální vzpomínky je daleko tě̌̌ší než sociálně 
konstruovanou kolektivní pamět'. Stěží se však lze ubránit pocitu, že Bourdieuho koncepce sledující především sociální linii kolektivní paměti se uchyluje $\mathrm{k}$ př́lilišnému zjednodušení takto pojaté rodinné paměti, při níž dochází k opomíjení individuálního rozměru paměti jednotlivých členů. Na rozdíl od Halbwachse, který nezapomíná zdůrazňovat roli individuální paměti $\mathrm{v}$ rámci kolektivní, která je jí př́mo nesena, Bourdieu prezentuje jednotlivce jako neschopné vystoupit, či alespoň se o to pokusit, z nekonečného kruhu rodinných rituálů. Ale i když tyto individuální interpretace minulého zřejmě nikdy nespatř́me okem nezainteresovaného diváka (kterým bezesporu jsme, nemluvíme-li o našich vlastních rodinných fotografiích), neznamená to, že jejich př́tomnost je pouze tušená.

\section{Síla dokumentace}

Jako prostředek dokumentování kolektivní paměti rodiny tedy fotografie sleduje, jak popisuje Pierre Bourdieu, fungování rodiny jako skupiny. Jaké jsou ale následky vstupu praktiky fotografování do rodinné paměti jako nástroje jejího zaznamenávání? Pojetí sociálně konstruované paměti v souvislosti s rolí dokumentačních technik rozvíjí ve své teorii „rámcư“ Erving Goffman (1974). Ne náhodou oba autoři ve svých pracích odkazují k úvahám Maurice Halbwachse. Goffman vychází z toho, že naše zkušenosti podléhají rámcům, tedy organizačním principům, které mohou být bud' př́rodní, či sociální. Sociálně konstruované rámce poskytují jakési pozadí pro naše chápání událostí, které v sobě zahrnuje vůli, záměr a jistou úroveň inteligence. Mohou být také popsány jako řízené konání (Goffman 1974: 22). Pro Goffmana představuje analýza rámců studium organizace zkušenosti. Tedy nikoli organizaci společnosti, ale zkušenosti individuálního aktéra, kterou disponuje v určitém okamžiku svého společenského života. Klíčový pojem přitom pro něj představuje „základní rámec“, čímž rozumí způsob pohledu na určitou událost, který není ovlivněn předem danými výklady. Právě základní rámec nám umožňuje interpretovat určitou scénu a její jinak nevýznamné aspekty jako mající význam.

Podle Goffmana se naše společnost vyznačuje vzrůstající tendencí využívání reprodukčních technik k zaznamenávání aktuálních událostí či činností za účelem jejich ustavení jako faktu, něčeho, co se v minulosti odehrálo. Jako príčiny rozšíření dokumentování uvádí Goffman magnetofonový pásek či videokazetu (samozřejmě vychází z dobových technologií 70. let), nesmíme ale zapomenout právě na fotografii jako jeden z nejrozšířenějších prostředků dokumentace. Excelentní pozorovatel Goffman ilustruje svoji sociologickou teorii řadou př́kladů z tisku a literatury, které čerpá z dlouholetého empirického výzkumu zaměřeného právě na sociální interakce. Jak Goffman ukazuje a sám poznamenává, je dosud podceňovaná moc „dokumentačního klíčování“ až impozatně působivá (Goffman 1974).

Zasazení určité situace do rámce vyžaduje znalost společně sdílených interpretačních vzorců, jejichž dešifrování nám umožňuje přiměřeně jednat v dané situaci. Každý základní rámec umožňuje svému uživateli lokalizovat, identifikovat a zařadit do patřičné skupiny jinak nesourodé množství konkrétních událostí. Dokumentace určité události může právě za přispění těchto sociálních rámců měnit jejich původní vyznění. Pokud se jedná o události, jako jsou různé rodinné rituály (narozeninové oslavy, svátky apod.), a jejich zaznamenávání, je tento rámec $\mathrm{z}$ velké části utvářen právě snahou po zachování kolektivní paměti rodiny. 
Dokumentační klíčování pak umožňuje stvrzení interpretace událostí podle záměrů rodiny, jejich uchování v určitých souvislostech.

Maurice Halbwachs (1992) mluví v podstatě o podobné sociální konstrukci paměti. Současně připouští, že rámce podléhají plynutí času, stejně jako se nacházejí mimo něj. Přirovnává je konkrétně $\mathrm{k}$ dřevěným vorům plujícím na řece tak pomalu, že je možné snadno přeskakovat $\mathrm{z}$ jednoho na druhý; přesto ale neustále nazadržitelně plují kupředu. Také Goffman príipouští, že se limity vlastní určitým druhům dokumentace mohou rapidně a během poměrně krátké doby proměňovat. Tak domnělá správnost stávajících limitů může jednou vzbuzovat hlubokou podporu, zatímco další rok mohou být stejné limity tiše porušeny, a rok poté se můžeme dočkat ratifikování této proměny. Historie je tu tedy sice sociálně konstruovaná, ale nikoli neměnná.

Sepjetí rodinné fotografie se skutečností se ukazuje jako daleko volnější, než se může zdát na první pohled. Jak poukázal Pierre Bourdieu (1990), následuje vytváření amatérských fotografií rodinné rituály a významné události, za účelem posílení upevňovacích mechanismů této skupiny. Vedle analýzy sociálního rámce však má na podobu rodinné paměti vliv také Bourdieuem poněkud opomenutá samotná logika fotografování, kterou reprodukční technika do události vnáší. Výsledkem fotografování založeného na logice objekt - divák, kdy se rodina stává pozorovaným objektem i svým vlastním divákem, je tak idealizovaný obraz rodiny. Fotografie jako nástroj paměti sloužící k reprodukování rodinného života pomocí dokumentačního klíčování poté stvrzuje ono konstatování „toto bylo“ v určitých souvislostech. Ustavuje sebe-interpretaci rodinné paměti jako faktu a činí z ní rodinnou historii. Vystoupíme-li však z rodinného kruhu, je zřejmé, že amatérské rodinné fotografie už pro nás nemohou fungovat jako opravdové svědectví minulého. Je možné však na ně pohližet jako na upomínky, u nichž není ani tak důležité, co a jak zobrazují, ale co v nás probouzejí.

\section{Paměf' společnosti}

Při uvažování o rodinné amatérské fotografii jako nástroji paměti je tedy nutné zohlednit jak pamět individuální, tak kolektivní. Jako mechanismus zaznamenávání paměti individuální slouží fotografie prostřednictvím selektivní činnosti k interpretování skutečnosti a vytváření obrazu o ní. Posléze znovu složené snímky pomocí individuální paměti pak vytváří z plurality okamžiků srozumitelnou, souvislou výpověd’.

Tyto individuální obrazy rodinné paměti jednotlivých členů skupiny tvoří opěrné piliřre pro pamět' kolektivní, která je konstruována sociálně. Na této úrovni, jak vyplývá z poznatků Pierra Bourdieu, fungují rodinné amatérské fotografie především $\mathrm{k}$ posílení upevňovacích mechanismů prostřednictvím dokumentování veskrze pozitivních zážitků. Určující je v tomto směru podle Maurice Halbwachse pro rodinu jako sociální skupinu stejně jako pro společnost požadavek její kontinuity. Proto také jak rodina, tak společnost eliminují ze své paměti vše, co by mohlo individua oddělovat.

Rodinná amatérská fotografie je tedy výsledkem procesu, v němž rodina ovlivňuje svoji vlastní historii. Zásadní přitom není ani tak manipulace $\mathrm{v}$ technické rovině fotografického záznamu, ale na úrovni praktiky fotografování, která zmáčknutí spouště předchází a která je odrazem logiky fotografického média. Souvisí přitom s jeho dokumentační funkcí, kdy 
z aktuálních událostí činí minulost. V intencích příslušných sociálních rámců pak dochází $\mathrm{k}$ interpretaci těchto událostí prostřednictvím fotografie vycházející ze snahy rodiny po vlastním sebepotvrzení.

Dokumentační potenciál fotografického média tak může být chápán nejen jako cenný nástroj reprodukování a uchovávání paměti, ale také jako prostředek, jak s naší historií manipulovat. Bez ohledu na technologický vývoj fotografie a možnosti, které přinesl v tomto směru nástup digitalizace, jsou obě tyto polohy vlastní fotografii už od jejích počátků. Následkem demokratizace tohoto média se stává značná část společnosti fotografem sebe sama a podílí se na vytváření stejně tak společné, jako vlastní historie. Z paměti by se proto především nemělo vytratit vědomí, že fotografie představuje pouze „bláznivý obraz načichlý realitou“" (Barthes 2005: 108).

\section{Literatura}

BARTHES, Roland. Světlá komora. 2. vyd. Praha : Agite/Fra, 2005. 123 s. ISBN 80-86603-28-8.

BATCHEN, Geoffrey. Burning with Desire. 1. vyd. Cambridge : MIT Press, 1999. 273 s. ISBN 0-26202427.

BATCHEN, Geoffrey. Ektoplasma. In Císař, K. Co je to fotografie? 1. vyd. Praha : Herrmann \& synové, 2004, s. 341 - 353. ISBN 80-239-5169-6.

BERGSON, Henri. Hmota a pamět'. Esej o vztahu těla a duchu. 1. vyd. Praha : OIKOYMENH, 2003. $191 \mathrm{~s}$. ISBN 80-7298-065-3.

BILLINGHAM, Richard. Ray's a Laugh. Zurich : Scalo, 2000. 112 s. ISBN 3-908247373.

BOURDIEU, Pierre. Photography. A Middle-brow Art. Stanford : Stanford University Press, 1990. 218 s. ISBN 0-804717605.

CHALFEN, Richard. Snapshot Versions of Life. Bowling Green : University Press, 1987. 213 s. ISBN 0-879723882.

DURKHEIM, Emile. Elementárni fromy náboženského života. 1. vyd. Praha : Oikoymenh, 2002. $491 \mathrm{~s}$. ISBN 80-7298-056-4.

FRIZOT, Michel. Photo trouvée. Paris : Phaidon, 2006. 319 s. ISBN 0-714845795.

FULKA, Josef. Bergsona a problém paměti. In ČAPEK, J. Filosofie Henri Bergsona. Praha : Oikoyment, 2003, s. 11 - 39. ISBN 978-80-72980-71-0.

GOFFMAN, Erwing. Frame Analysis. An Essay on the Organization of Experience. Boston : Notheastern University Press, 1974. 586 s. ISBN 0-93035091X.

GOFFMAN, Erwing. The Presentation of Self in Everyday Life. 1 vyd. New York : Doubleday, 1959. 259 s. ISBN 0-385094027.

HALBWACHS, Maurice. On Collective Memory. Chicago : The University of Chicago Press, 1992. 244 s. ISBN 0-226115968.

KRACAUER, Siegfried. Fotografie. In CÍSA $\breve{R}$, K. Co je to fotografie? 1. vyd. Praha : Herrmann \& synové, 2004, s. 27 - 44. ISBN 80-239-5169-6.

KUHN, Annette. Family secrets. Acts of Memory and Imagination. London : Verso, 2002. 196 s. ISBN 978-1859844069.

Le GOFF, Jacques. Pamět’ a dějiny. 1. vyd. Praha : Argo, 2007. 264 s. ISBN 978-8072038626.

MANOVICH, Lev. The Paradoxes of Digital Photography. In WELLS, L. The Photography Reader. New York : Routledge, 2003, s. 240 - 249. ISBN 0-41524661X.

MARTIN, Rosy ; SPENCER, Jo. Photo-terapy. Psychic realism as a healing art? In WELLS, L. The Photography Reader. New York : Routledge, 2003, s. 402 - 409. ISBN 0-41524661X. 
MITCHELL, William J. The Reconfigured Eye. Visual Truth in the Postphotographic Era. 1. vyd. Cambridge : MIT Press, 1994. 273 s. ISBN 978-0262631600.

MORAN, James M. Domácí tvorba a kulturní reprodukce. Teorie vědy, 2004, č. 2, s. $65-88$. ISSN 1210-0250.

SLATER, Don. Domestic Photography and Digital Culture. In LISTER, M. The Photographic Image in Digital Culture. 1. vyd. New York : London, 1995, s. 129 - 146. ISBN 0-415121574.

ŠILHANOVÁ, Jana. Analýza rámců Ervinga Goffmana. In ŠUBERT, J. a kol. Soudová sociologie II : Teorie sociálního jednání a sociálni strukutry. 1. vyd. Praha : Karolinum, 2008, s. 79 - 101. ISBN 978-80-246-1413-7.

VEBLEN, Thorstein. Teorie zahálčivé třídy. Praha : Sociologické nakladatelství, 1999. 344 s. ISBN 80-85850-71-0.

Základní aspekty a problémy. 1. vyd. Praha : OIKOYMENH, 2003, s. 11 - 39. ISBN 80-7298-071-8.

\section{Autorka}

je doktorandkou Falkulty sociálních věd UK. Magisterské studium na Vysoké škole uměleckoprůmyslové v Praze dokončila diplomovou prací na téma rodinná amatérská fotografie, jejíž výsledky prezentovala na workshopu „The Visual Archive: The Moving Image and Memory, The Open Unviersity, Milton Keynes, UK." Ve své disertační práci se zabývá sociální rolí nových médií v 90. v České Republice.

Kontakt: jinves@seznam.cz 